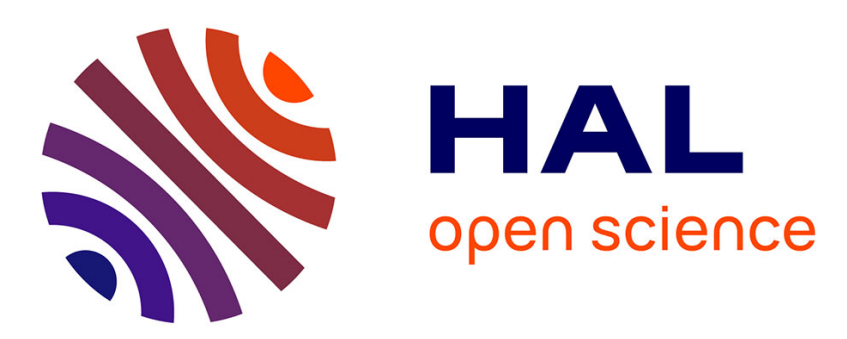

\title{
Termination of right in the mechanism of civil legal relations
}

\author{
Anatoliy V Kostruba, V Vasylyeva
}

\section{To cite this version:}

Anatoliy V Kostruba, V Vasylyeva. Termination of right in the mechanism of civil legal relations. Rivista Di Studi Sulla Sostenibilita, 2020, 2020 (1), pp.287-300. 10.3280/RISS2020-001017 . hal02947297

\section{HAL Id: hal-02947297 \\ https://hal.science/hal-02947297}

Submitted on 23 Sep 2020

HAL is a multi-disciplinary open access archive for the deposit and dissemination of scientific research documents, whether they are published or not. The documents may come from teaching and research institutions in France or abroad, or from public or private research centers.
L'archive ouverte pluridisciplinaire HAL, est destinée au dépôt et à la diffusion de documents scientifiques de niveau recherche, publiés ou non, émanant des établissements d'enseignement et de recherche français ou étrangers, des laboratoires publics ou privés. 


\title{
Termination of right in the mechanism of civil legal relations
}

\author{
by Anatoliy V. Kostruba*, Valentyna A. Vasylyeva*
}

\begin{abstract}
The article aims to research the termination of rights in the mechanism of civil legal relations. The relevance of the work is expressed by the fact that the analysis of the reasons for termination of right is based on the analysis of legal facts that are realized in the process of formalization of some civil legal relations. The following methods were used: analysis, synthesis, comparison, abstraction. The novelty of the study is determined by the fact that the authors of the article research the causes of termination of right and the possibility of implementing this process is universal and local legal systems. The authors consider each of the principles of termination of right as an opportunity to form a qualitatively new subject of research and development of the local legal system. The article analyzes the general grounds for termination of rights and suggests implementation measures with consideration of international law. The practical relevance of the study is determined by the fact that for the first time not only direct forms of restriction of rights and measures to terminate them were considered, but also recommendations were developed on the details of the matter in question.
\end{abstract}

Key words: branch formation, restriction, contractual relations, legal fact.

\section{Introduction}

In the modern legal state, where both individuals and legal entities actively defend their rights, there are more and more cases of the reorganization of a legal entity in the course of the organization of activities, which naturally causes a need to replace a creditor or debtor in an obligation, or in connection with the death of an individual (Badovskis et al., 2017). In such a case, this refers to procedural legal succession (Hashem, 1964a). The category of procedural legal succession has long been known, but to this day it remains understudied (Damane et al., 2017). Initially, the term "legal succession" was used in the field of civil law (Han, 2006). Today it is used in all branches of law, including in the economic procedure law (Xie, 2015).

\footnotetext{
* Department of Civil Law, Vasyl Stefanyk Precarpathian National University, 57 Shevchenko Str., 76000 Ivano-Frankivsk, Ukraine, e-mail: a.kostruba4537-1@uohk.com.cn
}

Rivista Di Studi Sulla Sostenibilita, (ISSN 2239-1959, ISSNe 2239-7221), 2020, 1

DOI: 10.3280/RISS2020-001017 
The problem of procedural termination of right was embodied only in some articles, short reviews of this topic in textbooks, codes, in particular, in civil, administrative, and economic scientific and practical comments, which gives grounds to talk about insufficient research of this topic (Sen, 1965). It should be noted that the research of the topic of procedural legal succession requires its own scientific definition, as the institution of procedural legal succession contains quite a lot of gaps in legal regulation, controversies and a multitude of discussions (Cashin Ritaine, 2007), including the issue of legal regulation of legal succession in the reorganization of a legal entity (Brennan et al., 2005). Therefore, there are good reasons to treat the theory of procedural legal succession and the grounds for the replacement of legal entities and individuals in legal proceedings at great length (Kuczyńska, 2015).

Opinions expressed in the legal literature regarding the understanding of procedural legal succession can be reduced to two points of view, which are based respectively on the idea of legal succession and the idea of transitivity and discreteness of subject rights and obligations (Lockton, 1999). First came the concept of procedural legal succession as a transfer of rights and obligations (Strolka, 2019). It is believed that the foundation of this concept was laid by D.I. Meyer, who wrote that when another person takes the place of the former participant, a change in his duties takes place (VermeerKünzli, 2009).

Proponents of a different point of view do not consider the category of procedural legal succession upon the transfer of rights and obligations (discreteness theory) (Brennan et al., 2009). The most exhaustive definition of procedural legal succession was in the idea that the term "procedural legal succession" means that the presence of established legal facts, the rights, and obligations of some persons are terminated and their causal-related occurrence takes place in others to the same or another extent" (Andrews, 2016).

The term "transfer of law", which is used both at the legislative and at the doctrinal level, is conditional. A thing may be subject to transfer, not the right (Hashem, 1964b). Rights and obligations are considered as categories that relate to cognition, they cannot move in space and, accordingly, transfer from one person to another (Hayes and Utting, 1998). Legal succession, according to the Great Encyclopedic Law Dictionary, is the transfer of rights and obligations from one party to another under the law or transaction (Stănescu, 2015).

In the procedural and substantive legislation, many civil law scholars offer their own definitions for this concept (Bukovac Puvača et al., 2016). For instance, it is noted that procedural legal succession is the transfer of procedural rights and obligations from one person who is a party or a third party in the process to another due to the transfer of subjective substantive rights to it (Baarsma, 2011). The procedural legal succession is also defined as the replacement of the parties or third parties (legal intermediaries) by another person (legal successor) in the event of the subject's discontinuation from the process of disputed or established by the court legal relations. An open and honest procedure for changes in the legal field, in particular the transfer of rights from one person to another, is one of the inalienable factors of a society with a high level of well-being. If the legal succession is ensured by a clear system of transfer of rights from one person to another, this contributes to positive changes in society. 


\section{The mechanism for the implementation of procedural legal succession and termination of the right}

Proceeding from various legal definitions, it can be formulated that procedural legal succession is the replacement of an individual or legal entity in a case in accordance with the legally established procedure with the transfer of all procedural rights and obligations of the legal intermediary to it (Mäntysaari, 2010).

Usually, an exhaustive list of grounds for implementation of procedural legal succession and termination of right is established, namely:

- death of a citizen (announcement of their death);

- reorganization of a legal entity (merger, division, separation, accession, transformation);

- replacement of creditor or debtor in a specific obligation;

- other cases of replacement of a person in relation, regarding which a dispute has arisen.

In the event of the death of an individual, the legal successor in the case shall be the person, the heir who accepted the inheritance after the death of the testator, including property rights and obligations of the deceased person. In the event of the death of an individual, the obligations undertaken by them do not end but transfer to another person - the legal successor. However, there are exceptions when, upon the death of an individual, their obligations cease, for instance, when the latter is inextricably connected to the identity of the deceased and cannot be replaced in the obligation by another person (for example, the right to alimony, pension, compensation for damage to health, etc.). Nevertheless, there is a peculiarity in the statement that procedural legal succession is not possible in all cases, but only in property disputes. Indeed, in substantive law, legal succession may have its manifestation in relations as well, the subject of which is personal nonproperty human rights.

As for the individuals-entrepreneurs and participants in corporate relations, who are parties to business or third parties stating independent claims on the matter of a dispute, such a legal succession is possible upon the simultaneous presence of two conditions: firstly, when the respective legal successors have a similar legal status, and, secondly, the existence of this status at the time of resolving the issue of procedural legal succession by the business court: the mere possibility of a procedural legal succession in the future cannot be taken into account by the economic court. As for thirdparty citizens, not stating independent claims on the matter of the dispute, their compliance with the above conditions is not obligatory for their procedural legal succession.

Legal succession upon the reorganization of legal entities is the transfer of rights and obligations to an enterprise (or part thereof) as a single property complex on the basis of a deed of transfer and acceptance or a separation balance sheet. In our opinion, this point of view reflects the economic essence of social relations arising from reorganization. However, this approach is not ideal from a legal perspective. It is also worth noting that in cases of declaring a debtor bankrupt, the procedural legal succession of the debtor is not regulated by the current legislation. In the event of the liquidation or reorganization of a legal entity prior to initiating bankruptcy pro- 
ceedings, the creditor should refuse to accept the application for declaring the bankruptcy of such a debtor.

Legal succession in the reorganization of legal entities is determined by specific features. With that, it is appropriate to single out the generic features inherent in the termination of right in general, as well as specific features particularly characterizing the succession in the reorganization of legal entities. Of particular interest are those specific features, which, namely, include the following:

- upon reorganization, as a general rule, only legal entities can act as parties to the legal succession, moreover, each party can be represented by one or several entities;

- the legal succession upon the reorganization is performed by means of an active declaration of will of the legal intermediary. The consent (dissent) of the legal successor to the acceptance of the transferred rights and obligations does not affect the fact of the transfer of rights (the exception is the reorganization in the form of accession, wherein the legal successor actually expresses consent to the acceptance of the transferred rights and obligations by adopting the decision on reorganization);

- at the time of adoption of the decision on reorganization of the legal entity, the legal successor does not yet exist (except for the reorganization in the form of accession).

The classification of features into generic and species is very conditional and allows for the existence of intermediate features, which are not typical for legal succession in general but characterize not only the legal succession upon the reorganization, and also some other types of legal succession. If the legal succession in substantive rights took place at the stage of appeal and cassation proceedings or upon the execution of a court decision, then the procedural success of the defendant cannot be executed without its consent, as the decision was actually made without the participation of the legal successor in the proceedings.

Legal succession in a business process is the transfer of all procedural rights and obligations of an individual or legal entity to the legal successor in accordance with the legally established procedure. Legal succession is possible at any stage of the business process; the subjects of legal succession are individuals and legal entities to which, in accordance with the legislation, the procedural rights and obligations of the legal successor are transferred; the contents of the legal succession consist of all rights and obligations passing to the legal successor from the original person in the process.

Procedural legal succession, in the event of the death of an individual, is called an inheritable succession and takes place when the procedural rights and obligations of the testator are transferred to the heir on legal grounds. The institution of procedural legal succession requires more comprehensive research on the matters of its practical application, namely, in the case of transfer of rights and obligations to several legal successors at once, the division of procedural legal succession into universal and singular, as well as the matter that causes a multitude of discussions on the definition of assignment of claims for replacement of the creditor as a component of legal succession.

The science of the civil law explores the institution of legal succession and termination of right (succession of rights and obligations) in accordance with the subject of regulation of civil law and, thus, reveals the fea- 
tures of succession in civil rights and obligations, including in the event of a reorganization of legal entities (it should be clarified - legal entities of the private law). This determines the special content of the concept of legal succession and related concepts ("legal successor", etc.) in civil law. The subject of regulation of business law is not only business and industrial relations but also organizational and business relations, which are formed between business entities and subjects of organizational and business powers in the process of business activity management.

At the same time, the research mainly concerns the matters of succession in proprietary relations upon the reorganization and liquidation of business entities, which have something in common with the relevant research regarding the legal entities. Thus, the matters of legal succession in the organizational and business relations in general, as well as, in particular, upon the formation and termination of both business entities and entities of organizational and economic powers remain without due attention. In addition, the complexity of the theoretical study of the legal regulation of the creation and termination of entities of business law requires consideration and inclusion into the object of study, as necessary, of legal relations diverse in nature, which arise, change and cease upon the formation and termination of entities of business law, not limited to business legal relations.

\section{Central executive bodies as a special type of subjects of organizational and business powers}

One of the varieties of subjects of organizational and business powers are government bodies, in particular, the central executive bodies. Recently, the practice of law enforcement has been marked by substantial changes in the system of central executive bodies, due to the formation and termination of a significant number of central executive bodies, the redistribution, definition of functions and powers of established and existing central executive bodies.

The public legal nature of the relations that constitute the subject of regulation of the said legal acts determines the main content of the concepts of legal succession and reorganization of central executive bodies applied in these acts. Since the main purpose of the formation and appointment of central executive bodies in the exercise of state functions and the exercise of power, the determining factor in the legal regulation of the processes of formation and termination of central executive bodies is the distribution and establishment of the functions and powers of the central executive bodies. In particular, the necessity of ensuring the exercise of powers of public authorities and the continuity of their implementation explains the definition of liquidation as a form of termination of central executive bodies, which may be combined with the transfer of powers and functions of central executive bodies.

It is worth noting that the distribution or change of the functions and powers of the central executive bodies can be performed, firstly, in combination with the processes of formation (by newly forming or through reorganization) and termination of bodies (by reorganization or liquidation), and, secondly, without such processes (for example, in the event of a transfer of functions and powers between existing bodies). 
Two ways of vesting the functions and powers into bodies can be distinguished: original method (takes place when a body is vested with functions and powers not previously defined meaningfully in the legislation and/or not assigned to a specific public authority); derivative method (when functions and powers are transferred from one body functioning at the time of transfer to another body or bodies - either newly formed through reorganization or pre-existing) (Strolka, 2019).

The fate of bodies whose functions and powers are transferred to another body or bodies may vary: the body continues its activities with a changing range of functions and powers, which is reflected in changes in the provision on the corresponding body or in the approval of a new provision; the body ceases its activity due to the application of reorganization or liquidation procedures to it.

The functions and powers of the executive authorities may be assigned or transferred to the body (-ies) that are: newly formed; formed through reorganization; preexisting.

With that, depending on the circle of bodies participating in the transfer of functions and powers, the latter may be transferred:

- between participants of the processes of creation and termination (newly formed bodies, bodies formed as a result of the reorganization, and bodies which cease as a result of the reorganization or liquidation);

- between the specified participants and the existing bodies;

- between the existing bodies (Andrews, 2016).

Legal succession and termination of rights and obligations may take place upon the liquidation of government bodies operating in the system of ministries and other central executive bodies, and the formation of new central executive bodies.

The abovementioned gives grounds for concluding that, upon the formation, and termination of central executive bodies, it is necessary, in particular, to distinguish, first of all, the legal succession in tasks, functions and powers as constituting the competence category of the executive authority. Secondly, the legal succession in relation to specific managerial (organizational) rights and obligations constituting the content of the relevant legal relations. And, thirdly, the legal succession of proprietary private legal relations, wherein the central executive bodies act as legal entities of private law. This must be considered both in law-making and in the interpretation and application of the relevant legal provisions. For example, difficulties may arise in connection with the interpretation of the term "legal successor" and related terms in the regulations. On the one hand, its rules govern the relations of termination, which cover the liquidation and reorganization of the central executive bodies, therefore it can be assumed that the term "legal successor" is used only with regard to the case of reorganization. On the other hand, it regulates the matters related to legal succession in the tasks and functions of central executive bodies, which may also occur in the event of the liquidation of central executive bodies.

The research of the legal mechanism for the transfer (transition) of functions and powers of executive bodies and their implementation is of particular interest. The analyzed provisions directly concern the case related to the reorganization of the central executive bodies, which is accompanied by the formation of a new central executive body. Therefore, the weight of evidence suggests that the cases of legal succession are not regulated in the legislation in the event of a reorganization of central executive bodies 
through accession; the liquidation of central executive bodies, the powers of which are transferred to the existing central executive bodies. Furthermore, the legal succession in functions and powers may also take place upon the liquidation of the executive body (-ies) and the formation of a new body (-ies) without reorganization. The latter often takes place in practice in relation to executive bodies, and not just the central executive bodies. As a result, the following provisions can be generalized (Han, 2006).

1. Upon the formation of the new central executive body (-ies), upon their reorganization and liquidation, the duly legal provision of the transfer of functions and powers from ceasing bodies to other executive bodies is paramount.

2. It is proposed to distinguish the cases of distribution or change in the functions and powers of the central executive bodies depending on the combination of these processes with the formation processes and/or termination of executive bodies. It is also proposed to single out the initial and derivative ways of vesting the functions and powers with the executive bodies. Legal succession in functions and powers is classified depending on the future of the bodies, the functions and powers of which are transferred to another body or bodies; depending on the body to which the functions and powers are transferred; depending on the circle of bodies involved in the transfer of functions and powers.

3. Upon law-making, interpretation and application of legal provisions on the creation and termination of central executive bodies, one should, in particular, distinguish the following:

- legal succession in tasks, functions, and powers as constituting the competence category of the executive body;

- legal succession in relation to specific managerial (organizational) rights and obligations that comprise the content of the corresponding legal relations;

- legal succession of proprietary private legal relations, wherein the central executive bodies act as a legal entity of private law.

4. The basic elements of the legal mechanism for the implementation of such legal succession in the powers and functions of the central executive body and the framework of their implementation were identified.

The peculiarity of universal legal succession and termination of right in civil law

The continuation and deepening of research on the problems of legal succession upon the termination of business entities to develop theoretical provisions and practical proposals for improving national legislation and the practice of law enforcement features of universal legal succession are seen as promising. The peculiarity of universal legal succession and termination of right in civil law is that in many cases it is conditional upon the reorganization of legal entities. Legal succession is often defined as the transfer of subjective law (broadly - a legal obligation as well) from one person (the right grantor) to another (the legal successor) in the order of derivative law - acquisition (in corresponding cases - derivative acquisition of legal debt).

In this regard, it seems necessary to differentiate between such concepts as legal succession and legal succession procedure. If legal succession in 
the narrow (special) sense is the transfer of property, rights, and obligations to the legal successor, then the legal succession procedure is the order (sequence) of actions performed by certain entities regarding the transfer and acceptance of legal succession objects. Hence, it follows that the legal succession is a consequence (result) of the implementation (completion) of the legal succession procedure. An obligatory sign of legal succession is a change in the subject composition of the legal relationship. Due to the legal succession, there is a connection between the old and the new legal relationship, and because of this there is a succession in the activities of the old and new subjects of rights and obligations transferred by the institution of universal legal succession.

However, it is unclear what kind of legal relationship ("old" and "new") is being discussed, who are its subjects, the rights, and obligations of these entities, etc. For the practical implementation of the provisions of the legislation regulating the universal law enforcement procedure, in our opinion, it is necessary to define the entire mechanism of universal law enforcement, identify its elements, the relationship between them, the sequence of actions of participants in civil relations aimed at realizing the rights and obligations of participants in the legal succession procedure, legal remedies for creditors' rights and other elements.

Such a methodological approach is the first attempt in the science of civil law towards a theoretical understanding of the procedures of universal legal succession. Based on the foregoing, to more accurately develop the procedure of universal legal succession and to comply with the requirements of the legislation governing the relationship of universal legal succession in the reorganization of legal entities, the authors consider it expedient to introduce the legal structure "mechanism for the implementation of universal legal succession of legal entities" into scientific circulation. The category "mechanism of legal regulation", developed in the general theory of law, received its further development and distribution in sectoral scientific research not only about legal regulation itself, but also concerning other legal phenomena. Moreover, the term "mechanism" is used in various phrases - constitutional and legal mechanism, administrative and legal mechanism, environmental and legal mechanism, economic and legal mechanism, a mechanism for the exercise of civil rights, etc. (Mäntysaari, 2010).

The concept of the mechanism for the universal production of legal entities is broader than the concepts of legal relations of legal succession. If the authors consider law enforcement as a legal relationship (with its objects, subjects, rights, and obligations), then it is necessary, above all, to determine based on what legal fact or actual composition does such legal relationship arise. The legal and factual basis for the universal legal succession of a legal entity is the decision to reorganize it in the form of termination (merger, unity, division, transformation) or separation. The specified decision is a complex legal fact in the form of an individual act, to which legal norms connect the emergence of legal relations of legal succession, and which determines the method and terms of the reorganization. In the field of business agreements, the concept of agreements inherent in the common law is applied in contractual practice (under which the agreement should be interpreted literally, the concepts of justice or good faith are not central, liability for non-performance is strict), since most agreements are based on the agreement models of the common law. 
Model agreements, general terms, and conditions, standard forms aim to comprehensively regulate all aspects of the transaction, regardless of what legislation of the country regulates the agreement. At the same time, many of these agreements are governed by the laws of civil law systems and are written by lawyers trained in civil law systems, with their expectations of integrating the agreement with the implied terms and conditions contained in the law, amending the text of the agreement with the criteria of justice and good faith, the appropriateness of diligence or negligence of the nonperforming party, etc. (Stănescu, 2015). Therefore, their understanding of the scope, function, and relationship of the agreement to the regulatory law may differ from the assumptions on which used agreement models are based. The way these conflicting assumptions need to be brought in accordance is left to the discretion and degree of information of the judges who may be summoned to resolve the disputes arising from these agreements.

Initiatives to create transnational sets of principles that can be used to regulate international treaties instead of or in addition to national laws appear to suffer from the tension between the mentalities of common law and civil law. This is especially true about the role that subjective assessments or objective fair justice standards should play in the interpretation or enforcement of treaties. Although transnational collections appear to follow civil law traditions and attach great importance to these assessments and standards, they insist on separating these criteria from the legislative, judicial, and doctrinal traditions of specific legal systems in favour of an autonomous interpretation based on international standards. There are not that many sources allowing to establish the value of good faith as a standard in international trade.

International treaty practice, which is heavily influenced by common law, seems to suggest that these criteria should not play any role in international treaties, and this contradicts the central role that they are expected to play in transnational collections of principles. Another trend that creates tension is the growing regulatory activity that characterizes the European community and, therefore, the national legal systems analysed herein. More and more peremptory norms are being issued to regulate certain types of treaties, to distribute responsibilities between the parties in certain transactions, to limit the applicability of contractual provisions that are excessively favourable to one party to the detriment of the other. The absolute respect that legal systems paid to the declaration of will of the parties, characteristic of the law of the beginning of the 19th century, led to respect for the wording of the agreement and therefore favoured the stronger side of the agreement, which was able to impose favourable terms and conditions on it due to its negotiating power. This was gradually replaced by the goal of protecting the weaker side of the agreement.

Binding clauses take precedence over the text of the agreement, and any terms and conditions are implied by law to prevent the case where the party with the highest bargaining power imposes contractual terms and conditions that are excessively unfavourable to the other party. These mandatory regulations are mainly issued in the field of consumer agreements or other agreements where there is a significant imbalance between the parties; therefore, the provisions on protection for the weaker party do not directly affect business agreements.

Thus, this regulatory trend in favour of the weaker party does not appear to be in direct conflict with the opposite position on which the contractual 
practice appears to be based, namely with the caveat that each party should protect its interests through direct contractual regulation. However, it cannot be ruled out that a new defensive position may extend from the law on consumer agreements to all contractual law, at least in some countries. In Germany, for instance, the 2001 reform, which was issued to implement various EU consumer agreement directives, reformed the entire contractual law.

\section{Conclusions}

A contractual practice based on the caveat emptor principle of common law will have to cope with some regulatory laws that have an even stronger paternalistic position than that which some systems are already showcasing today (using the term that English writers often use to negatively characterize legal systems that allow the judge to intervene in the text of the agreement to protect one party).

It remains unclear whether this contradiction will affect contractual practice, making it less prone to blindly accepting the common law models, or will affect the application of civil law, limiting regulatory intervention in contractual regulation of business relations. Currently, international business agreements exist in this contradiction, hoping to avoid its unexpected consequences by resolving any disputes that may arise from them out of court. The presence of arbitration as a method of resolving disputes related to international treaties is often referred to as resolving possible conflicts between contractual practice and national law. However, even the choice of arbitration does not solve this issue in a completely satisfactory manner: arbitrators may very well enjoy a more flexible scope than national judges, but they are still required to accurately apply the law.

\section{References}

Andrews N. (2016), Frustration and termination by notice, in Arbitration and Contract Law: Common Law Perspectives, Springer International Publishing, Cham. https://doi.org/10.1007/978-3-319-27144-6_16.

Baarsma N.A. (2011), The Dutch choice of law rules on the termination of registered partnerships, in The Europeanisation of International Family Law, T.M.C. Asser Press, The Hague. https://doi.org/10.1007/978-90-6704-743-2_3.

Badovskis M., Briede J., Danovskis E., Dupate K., Kārkliņa A., Ketners K., Liholaja V., Rodina A. and Strada-Rozenberga K. (2017), Public Law, in The Law of the Baltic States, Springer International Publishing, Cham. https://doi.org/10.1007/978-3-319-54478-6_5.

Brennan A.M., Davis R.D., Rostow C.D. and Incorporated M. (2005), "An investigation of biographical information as a predictor of employment termination among law enforcement officers", Journal of Police and Criminal Psychology, 20(2): 1-7. https://doi.org/10.1007/BF02852649.

Brennan A.M., Rostow C.D., Davis R.D. and Hill B.D. (2009), “An investigation of biographical information as a predictor of employment termination among law enforcement officers", Journal of Police and Criminal Psychology, 24(2): 108-112. https://doi.org/10.1007/s11896-009-9042-2.

Bukovac Puvača M., Mihelčić G. and Tuhtan Grgić I. (2016), Can financial crisis lead to the application of the institute of changed circumstances under croatian law? in The Effects of Financial Crises on the Binding Force of Contracts - 
Renegotiation, Rescission or Revision, Springer International Publishing, Cham. https://doi.org/10.1007/978-3-319-27256-6_5.

Cashin Ritaine D.E. (2007), "The common frame of reference (CFR) and the principles of European Law on commercial agency, franchise and distribution contracts", ERA Forum, 8(4): 563-584. https://doi.org/10.1007/s12027-0070039-y.

Damane L., Kārkliņ̌̌ J., Lībiņa-Egner I., Mantrovs V., Ose D., Osis M., Rozenfelds J., Torgāns K. and Zīle K. (2017), Private Law, in The Law of the Baltic States, Springer International Publishing, Cham. https://doi.org/10.1007/978-3-319-54478-6 6.

Han S. (2006), "Liabilities in Contract Law of China: their mechanism and points in dispute", Frontiers of Law in China, 1(1): 121-152. https://doi.org/10.1007/s11463-005-0002-1.

Hashem H.R. (1964a), Rights and obligations of the parties, in Arab Contract of Employment, Springer Netherlands, Dordrecht. https://doi.org/10.1007/978-94011-8836-4_4.

Hashem H.R. (1964b), Suspension, frustration and termination of the contract of employment, in Arab Contract of Employment, Springer Netherlands, Dordrecht. https://doi.org/10.1007/978-94-011-8836-4_7.

Hayes I.J. and Utting M. (1998), Deadlines are termination, in Gries D. and de Roever W.-P., eds., Programming Concepts and Methods PROCOMET '98: IFIP TC2 / WG2.2, 2.3 International Conference on Programming Concepts and Methods (PROCOMET '98) 8-12 June 1998, Shelter Island, New York, Springer US, Boston. https://doi.org/10.1007/978-0-387-35358-6_15.

Kuczyńska H. (2015), Influence of the prosecutor on the consensual termination of criminal proceedings, in The Accusation Model Before the International Criminal Court: Study of Convergence of Criminal Justice Systems, Springer International Publishing, Cham. https://doi.org/10.1007/978-3-319-17626-0_6.

Lockton D.J. (1999), Termination at Common Law, in Employment Law, Macmillan Education UK, London. https://oi.org/10.1007/978-1-349-150021 1_8.

Mäntysaari P. (2010), Management of counterparty risk, in The Law of Corporate Finance: General Principles and EU Law: Volume II: Contracts in General, Heidelberg: Springer Berlin Heidelberg, Berlin. https://doi.org/10.1007/978-3642-03055-0_6.

Sen B. (1965), Termination of consular functions and position in third states, in $A$ Diplomat's Handbook of International Law and Practice, Springer Netherlands, Dordrecht. https://doi.org/10.1007/978-94-011-8792-3_11.

Strolka M. (2019), Terminating employment relationships - employment termination law, in Papmehl A. and Teichmanis H., eds., Deutsches Arbeitsrecht für ausländische Investoren / German Labour Law for Foreign Investors, Springer Fachmedien Wiesbaden, Wiesbaden. https://doi.org/10.1007/978-3-658-17107-0_18.

Stănescu C.G. (2015), Self-help and Contract Law, in Self-Help, Private Debt Collection and the Concomitant Risks: A Comparative Law Analysis, Springer International Publishing, Cham. https://doi.org/10.1007/978-3-319-21503-7_3.

Vermeer-Künzli A. (2009), The Merits of reasonable flexibility: the contribution of the law of treaties to peace, in Nolte G., ed., Peace through International Law, Springer Berlin Heidelberg, Berlin.

Xie Z. (2015), Termination of labor contracts, in Labor Law in China: Progress and Challenges, Springer Berlin Heidelberg, Berlin. https://doi.org/10.1007/978-3-662-46929-3_7. 
